\title{
The Effect of Guided Discovery Learning Model with Superitem Test on Students' Problem-Solving Ability in Mathematics
}

\author{
Evi Hulukati (Corresponding author) \\ Department of Mathematics, Faculty of Mathematics and Natural Science, \\ Universitas Negeri Gorontalo, Gorontalo, Indonesia \\ E-mail: eviemega@yahoo.com
}

Siti Zakiyah

Department of Mathematics, Faculty of Mathematics and Natural Science,

Universitas Negeri Gorontalo, Gorontalo, Indonesia

\begin{abstract}
Ali Rustam
Department of Mathematics, Faculty of Mathematics and Natural Science, Universitas Negeri Gorontalo, Gorontalo, Indonesia
\end{abstract}

Received: May 20, 2018 Accepted: July 19, 2018 Published: July 21, 2018

doi: 10.5296/jsss.v5i2.13406 URL: http://doi.org/10.5296/jsss.v5i2.13406

\begin{abstract}
This experimental study aims to compare problem-solving abilities between students that are taught with guided discovery learning models and conventional learning models. This study involved all eighth graders as the research population. Furthermore, the sampling technique used is the simple random sampling technique in two classes in Junior High school SMPN 1 Kota Gorontalo by employing Superitem essay test as a data collection tool. This descriptive analysis is described in the frequency distribution and histogram tables, whereas inferential analysis was performed by using ANCOVA test. The results showed that guided discovery learning model is preferable to compare to the conventional learning model in improving
\end{abstract}


mathematics problem-solving ability.

Keywords: Discovery Learning Models, Problem-solving abilities, Superitem test

\section{Introduction}

Teacher as a facilitator, organizer, and motivator implementing the learning process in mathematics should be able to choose the appropriate learning model corresponding to mathematical subject characteristics that allow the student problem-solving abilities development. As a facilitator, teachers prepare learning devices that enable students to find their concepts, principles, and procedures through a series of learning activities. As an organizer, a teacher must be able to manage the course of the learning process, including ways to intervene and engage students in understanding the concepts, principles, and procedures. As the motivator, teachers give the motivation to students who are less active in the learning process. Thus, the role of the learning approach that selected by teachers is very strategic in imparting mathematical concepts.

The low learning outcome of mathematics is caused by several factors including the achievement which is more focused on the achievement of learning from the target, not the students' understanding of mathematical concepts. Also, classroom activities make teachers more active than students. Consequently, children do not have critical thinking. To make students more active, it is essential to get the students to communicate and participate in each learning activity actively.

Another problem related to mathematics learning is the concern of teachers in understanding Student Problem Solving Abilities. This can be seen in the lack of learning management to support the development of particular competencies. General mathematics of the Problem-Solving Ability plays a vital role in each student. In the teaching and learning process of mathematics, when a question was given to students, then the students should be able to identify, understand, analyzing, and reuse the argument to solve the problem. The problem-solving ability is also one of the mathematics that should receive top priority in mathematics learning. In the recommendations of $\operatorname{NCTM~(1989:~2),~said~that~}$ problem-solving skills should be the focus of learning in mathematics. This recommendation is not only a skill that shows that problem solving is essential but also implies that some effort must be made to include it in an integral part of the mathematics curriculum objectives.

Learning model that has been applied less able to develop students' problem-solving abilities as such, many students understand the material being taught are just as described, then they usually forget the concept of what is being taught. Mathematics learning problem in schools today is teachers tend to achieve mastery of the material to be taught at the time the target is available. This condition illustrates that teachers are unconcerned with the underlying things that significantly affect students in acquiring the knowledge taught to them. The learning process that emerges is the achievement of learning-oriented learning materials rather than learning that focuses on improving student competence. Under these conditions, it is not surprising that mathematical results are low.

Guided discovery learning using the form Superitem task, besides directing students to discover concepts, rules, and procedures, it can help train the students' problem-solving ability that can be used optimally and ultimately to improve student learning outcomes. 
According to Biggs and Collis that tests in the form of superitem are made based on the SOLO student stages. Students work on simple problems then move to more complex tasks. This process can optimize the application of mathematical problem-solving skills and accelerate students' understanding of a concept, which will ultimately be a positive influence on student learning outcomes.

\section{Review}

\subsection{Problem Solving Ability in Mathematics}

Polya (1985) defines problem-solving as an attempt to find a way out of trouble in order to achieve goals that are difficult to achieve. While Dahar (1989) said that problem-solving activity is a human activity in applying the concepts and rules that obtained previously. While the National Council of Supervisors of Mathematics (Branca, 1980) stated that learning to solve problems is the principal reason for teaching mathematics. Problem-solving is a process to apply the previously acquired knowledge to the new or unusual situations. Solving the word problems is one form of problem-solving, but students also need to know and be familiar with routine matters.

Russefendi (1991) said that solving the problem is a general approach that is more about the process than the result (output). Therefore, the aspect of the process is a key aspect of the learning problem solving, rather than aspects of the product, as found in conventional learning (traditional). The understanding of the process in this case, according to Sabandar (2001), contained meaning that when students learn mathematics, there is a process of reinvention (rediscover). It means that procedures, algorithms, and rules that must be learned is not provided and taught by teachers and students have to find it themselves.

Based on the definition above, problem-solving is a real effort to find a way out of the problems encountered in daily life or specific issues for achieving the goals set. Problem-solving should actively involve students in the learning process, including students to experiment with ideas and materials so that students can actively develop knowledge. Student engagement means that they are actively searching for themselves, finding their own or formulating their conclusions. Thus, an understanding of the concept-forming process is preferred.

Mathematics learning with problem-solving approach helps teachers to connect the mathematics ideas to real-world situations and motivates students to make connections between knowledge and its application in their daily lives. Otherwise, the student must be able to translate the everyday sentences into math sentence. Incapacity of a student, in this case, is one of the sources of error in solving mathematical problems.

Solving math problems requires the right concrete steps to get the correct answer. A variety of views on the problem-solving steps proposed by some experts are structured so that we may solve the problem correctly. Witting \& Williams (1984) suggested the following problem-solving steps: (1) formulating the problem, (2) processing and troubleshooting, and (3) evaluating the problem-solving.

These steps were taken in solving the problem using the steps recommended by Polya (1985) which proposed the problem-solving steps in four stages: (1) understanding the problem, (2) preparing the plan, (3) executing the plan, and (4) re-examine the process and results 
(retrospect). Russefendi (1991) considers that additional steps may complement Polya's steps, then he proposed modifications to Polya's steps as follows, (1) rewriting the words themselves, (2) writing equations, (3) write ways to solve as coping strategies, (4) discuss ways of settlement, (5) work, (6) reexamine results, and (7) choose the solution.

From the various stages of problem-solving mentioned above, there is almost no significant difference in meaning. All the problem-solving stages mentioned before containing the main stages proposed by Polya.

\subsection{Superitem Test}

Superitem test is a test developed by taxonomic SOLO used as a means of alternative assessments to monitor the development of cognitive abilities of students in solving mathematical problems (Collis, Romberg, and Jurdak (1986), Lam and Foong (1998), Wilson and Iventosh (1988)). Superitem tests consist of situational problems and four complex and intertwined items. This test consists of problem situations, drawings or graphs, whereas items comprised of four levels of reasoning based on the SOLO model taxonomy as follows:

- Unistructural. Students focus on one or more relevant information to give a response to the reality of the concrete was directly involved in the issue. For example, students use and refer to the concrete object (picture) given in the stem to find the next pattern from the current pattern.

- Multistructural. Students use the more relevant information to get a solution, but not to integrate it. For example, students begin to identify the relationship between variable patterns and be able to explain how these patterns are moving in the sequence.

- Relational. Students integrate each aspect of the given information into a coherent structure. In other words, the information provided is sufficient to solve the problem.

- Extended abstract. The student generalizes the structure into a new and more abstract concept.

From a few steps of guided discovery learning model proposed by the experts, in this research we used measures proposed by Markaban. Based on the description above, we concluded that the test in superitem form is good to use with the model of guided discovery learning. The steps of the application of guided discovery learning model by using test superitem form are as follows:

- The teacher divides the students into groups consisting of 4-6 students

- Teacher briefly explain the material to be studied

- Teacher gives assignment test superitem form as a medium for guided discovery learning

- The teacher describes the purpose and procedures of activities that must be performed

- Checking that all students understand the purpose and procedures of the activities to be carried out

- From the data in superitem test form given by the teachers, students prepare, process, organize and analyze data.

- Teachers guide students through the process of guided discovery through direct questions. In this case, this guidance should lead students to go directly to the destination, through the leading questions. 
- Students discuss in groups to formulate a conjecture (forecasts) and the results of the analysis done.

- If it is necessary, the conjecture has been made by the students above by teachers. It is essential to convince students for casts, so it will be towards the direction to be achieved. This activity can be done through a presentation of results and a representative of each group.

- If it has been assured of the truth of conjecture, the conjuncture must also be conveyed to the students to incorporate it.

After the students discover what they search, the teacher should provide the additional exercises or problem to reinforce students understanding the concepts that have been found.

\section{Methods}

This research was conducted in the Junior High School SMPN 1 Gorontalo. This research took place in the second semester of 2013/2014. The type of this research was quasi-experiment (pseudo-experiment), by using a Pretest-Posttest Control Group Design as a research design. (Arikunto, 2002:79) (Table 1).

\subsection{Variables}

The independent variables in this study were divided into (1) the "experimental classes" classes that used the learning approach to model the discovery of social interactions and (2) the "control classes" - classes that used conventional learning method. The depending variable was the "mathematical problem-solving ability," while the companion variable in this study was the "initial ability indicated by the pretest score" (Table 1).

Table 1. Variables related to each group

\begin{tabular}{llll}
\hline Class & Pretest & Treatment & Posttest \\
\hline Experiment & $\mathrm{O}_{1}$ & $\mathrm{X}_{1}$ & $\mathrm{O}_{2}$ \\
Control & $\mathrm{O}_{1}$ & $\mathrm{X}_{2}$ & $\mathrm{O}_{2}$ \\
\hline
\end{tabular}

\subsection{Population and Sampling}

The population was all eighth-grade students in Junior High School SMPN 1 Kota Gorontalo. The sample was students from class VIII.6 and VIII.7 acquired by simple random sampling.

\subsection{Data Collection}

There were two data needed: (1) the initial mathematics ability collected from the pretest and (2) the problem-solving ability collected with a superitem test from the posttest. We use the scoring system as follows: 
Table 2. Scoring system for problem-solving ability

\begin{tabular}{|c|c|c|}
\hline Aspect & $\begin{array}{l}\text { Respons to } \\
\text { the question or problem }\end{array}$ & Score \\
\hline \multirow[t]{3}{*}{ Understanding the problem } & $\begin{array}{l}\text { Does not understand the point of question or does } \\
\text { not have answers }\end{array}$ & 0 \\
\hline & $\begin{array}{l}\text { Does not follow the test requirements or fail to } \\
\text { interpret the question }\end{array}$ & 1 \\
\hline & Understand the question well & 2 \\
\hline \multirow{5}{*}{$\begin{array}{l}\text { Planning the strategy to } \\
\text { complete the question }\end{array}$} & No strategy or plan & 0 \\
\hline & Irrelevant strategy & 1 \\
\hline & $\begin{array}{l}\text { Use specific strategy, but can not complete the } \\
\text { plan or choose the wrong step }\end{array}$ & 2 \\
\hline & Use any strategy which leads to the wrong answer & 3 \\
\hline & $\begin{array}{l}\text { Use some appropriate strategies that could lead to } \\
\text { the correct answer }\end{array}$ & 4 \\
\hline \multirow[t]{5}{*}{ Executing the strategy plan } & The strategy is not executed & 0 \\
\hline & $\begin{array}{l}\text { There is an attempt to execute the plan but in } \\
\text { the unclear procedure }\end{array}$ & 1 \\
\hline & $\begin{array}{l}\text { Use one procedure that could lead to the correct } \\
\text { answer }\end{array}$ & 2 \\
\hline & $\begin{array}{l}\text { Use the appropriate procedure but wrong in } \\
\text { calculation }\end{array}$ & 3 \\
\hline & $\begin{array}{l}\text { Use the appropriate procedure and that finally end } \\
\text { with the correct answer }\end{array}$ & 4 \\
\hline \multirow[t]{4}{*}{ Validating answers } & Does not recheck both the process and the answer & 0 \\
\hline & Only recheck the answer (the calculation) & 1 \\
\hline & Only recheck the process & 2 \\
\hline & Recheck the process and the answer & 3 \\
\hline
\end{tabular}

\subsection{Data Validation and Reliability}

Pearson product-moment of correlation was used to validate the linear correlation between variables using formula as follows: 


$$
r_{x y}=\frac{N \sum X Y-\left(\sum X\right)\left(\sum Y\right)}{\left.\sqrt{\left\{N \sum X^{2}-\left(\sum X\right)^{2} \int^{2} \sum Y^{2}-\left(\sum Y\right)^{2}\right.}\right\}}
$$

(Sugiyono, 2005: 213)

The Cronbach alpha was used to estimate the reliability of the test.

$$
r_{i}=\frac{k}{(k-1)}\left\{1-\frac{\Sigma s_{i}^{2}}{s_{t}^{2}}\right\}
$$

(Sugiyono, 2005: 282)

\subsection{Data Analysis}

Data were analyzed using covariant inferential analysis (ANCOVA). This general linear model evaluates whether the population mean of the dependent variable is the same across all levels of categorical independent variables (experimental and control classes), while statistically controlling the effects of other continuous variables as covariates. (first mathematics ability) (Gultom, 2013).

\section{Results}

\subsection{Lesson Plan}

The learning plan is developed by the researcher and validated by the validator. Assessments provided by the validator include the format, language, and content of the lesson plan. The validation results show that the average score of the two assessment assessments of the eligibility of the Lesson Plans provides an appropriate assessment. However, there are several suggestions for improvements from the validator are: determining the indicators, learning objectives, and the Lesson Plan phase.

\subsection{Students' Worksheet}

Student worksheets in the form of superitem tests developed by researchers are a guide for students to learn with teachers as facilitators as well as self-training exercises to understand the concept of the material being studied.

Worksheets are developed and validated by experts/specialists. Valid aspects include formatting, content, and language. Based on the result of the feasibility assessment sheet, the average validator score given in each category is quite good. This indicates that the developed worksheet can be used for eighth-grade junior high school students. However, there are some improvement suggestions related to questions that have not been able to measure the achievement of the learning objectives in the lesson plan.

\subsection{Result Description}

The experimental class is taught with an ecosystem self-discovery learning model, and the control class taught by cooperative learning model consists of 34 and 32 students respectively. Table 4, Figure 1 and Figure 2 show the pretest and posttest scores collected from the sample. 
Table 4. Pretest and posttest score

\begin{tabular}{lllll}
\hline & Pretest Score & & Posttest score \\
& Expr Class & Ctrl Class & Expr Class & Ctrl Class \\
\hline $\mathrm{n}$ & 32 & 34 & 32 & 34 \\
Max & 80 & 76 & 90 & 96 \\
AMin & 36 & 40 & 40 & 42 \\
Mean & 64,00 & 57,00 & 82,34 & 72,38 \\
Modus & 61,83 & 54,25 & 76,50 & 78,25 \\
Median & 63,88 & 56,50 & 80,17 & 70,50 \\
SD & 13,32 & 11,56 & 14,99 & 13,28 \\
Variance & 177,29 & 133,64 & 224,59 & 176,47 \\
\hline
\end{tabular}

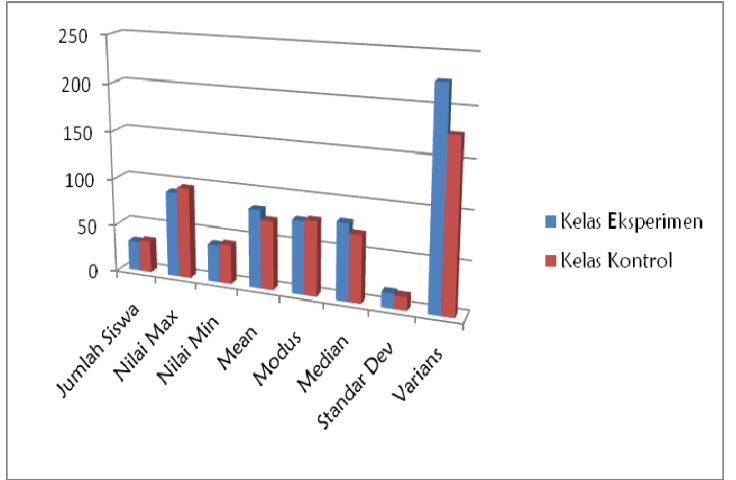

Figure 1. Bar chart showing the pretest score in experiment and control classes

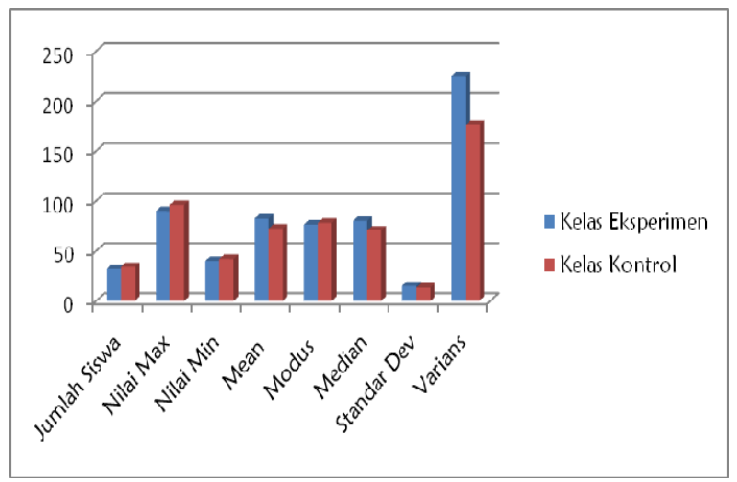

Figure 2. Bar chart showing the posttest score in experiment and control classes

\subsection{Inferential Analysis}

The mean of pretest and posttest scores is listed in Table 5 and illustrated in Figure 3.

Table 5. Pretest and posttest mean values

\begin{tabular}{lll}
\hline & Pretest Score & Posttest Score \\
\hline Control Class & 57,06 & 72,41 \\
Experiment Class & 62,13 & 82,19 \\
\hline
\end{tabular}

The difference of the value of pretest and posttest from experimental class and control class, it is explained in the graphic below: 


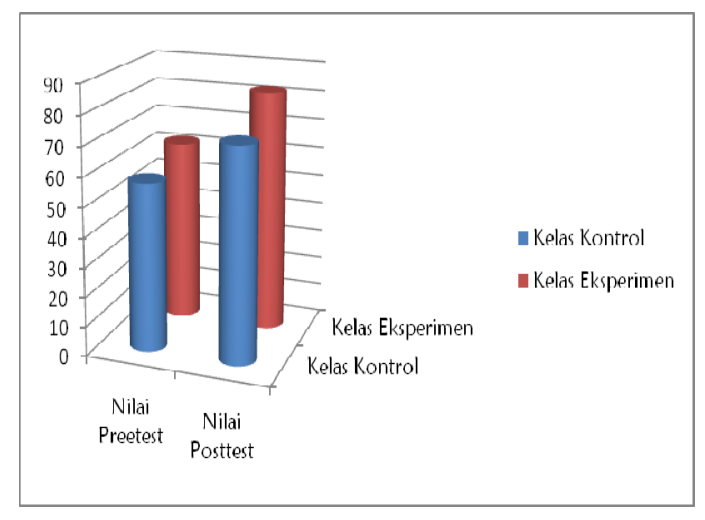

Figure 3. Pretest and posttest mean scores

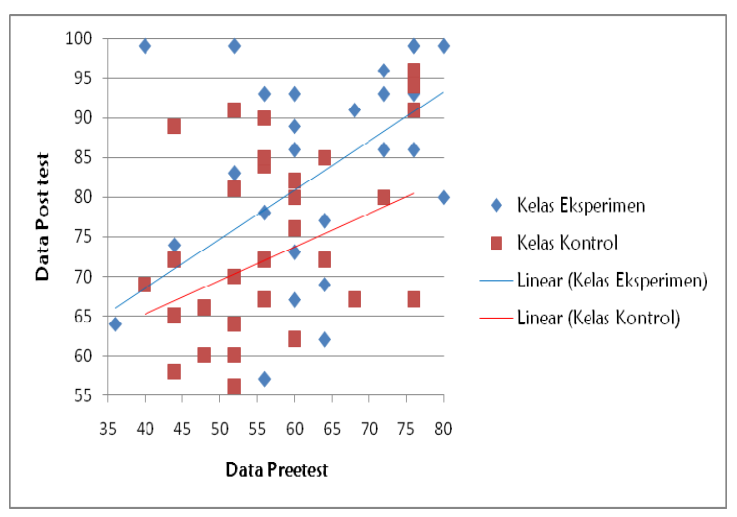

Figure 4. The regression line shows the connection between each learning model used and the problem-solving ability of the students in both classes

Two simple regression models were obtained based on the inferential analysis. The first represents the relationship between the first mathematics capability with the problem-solving ability of the students taught with the guided discovery model ( $\mathrm{Ye}=0,61943,6841+\mathrm{Xe}$ ). The second represents the relationship between the initial mathematics capability with the problem-solving ability of the students taught with the cooperative learning model (Yk = $48,2617+0,423 \mathrm{Xk}$ ). The regression coefficient significant test (independent test) for both regression models show that the initial mathematics capability has a significant influence towards the problem-solving ability.

The regression line of the experiment and control classes was parallel, but the constant of the regression line of the experiment class is more significant than the control class. This indicates that there is a substantial difference as shown in Figure 4.

These results suggest that the guided discovery learning model is more superior than the cooperative learning model in increasing the problem-solving ability in mathematics superitem test.

\section{Conclusion}

Our study suggests that the initial student capability in mathematics have significant influence on the problem-solving ability. Based on the hypothesis criteria, we will accept the null hypothesis if $F_{\text {count }}$ is greater than $F_{\text {table }}$ and the inferential analysis result is consistent with this statement. The $F_{\text {count }}$ is 0.29979 , and the $F_{\text {table }}$ is 4.00 . It means that the guided discovery learning model is more effective than the cooperative learning model in increasing the problem-solving ability in mathematics.

\section{Refferences}

Bigg, J. B., \& Collis K. F. (1982). Evaluating the quality of learning: The SOLO taxonomy (structure of the observed learning outcome). Retrieved from: Google Books. https://doi.org/10.1016/B978-0-12-097552-5.50009-0 


\section{Macrothink}

Journal of Social Science Studies

ISSN 2329-9150

2018, Vol. 5, No. 2

Burke, M. J., \& Curcio, F. R. (2000). Exploring mathematics through talking and writing. USA: NCTM

Dahar, R.W. (1989). Konstruktivisme dalam mengajar dan belajar (Unpublished Professorial Oration). FP-MIPA IKIP Bandung, Bandung.

Hudoyo, H. (1996). Mengajar belajar matematika. Jakarta: Depdikbud Dirjen DIKTI P2LPTK.

Markaban. (2006). Model pembelajaran matematika dengan pendekatan penemuan terbimbing. Yogyakarta.

National Council of Teachers of Mathematics (NCTM). (1980). An Agenda for action: Recommendation for school mathematics of the 1980s. Reston. Virginia: NCTM.

NCOTO Mathematics, Inc, Reston. (1989). Curriculum and evaluation standard for school mathematics. Reston. Va: NCTM.

Polya, G. (1985). How to solve it. an new aspect of mathematical method (2nd ed.). New Jersey: Princeton University Press.

Romberg, T. A. (1992). Problematic feature of the school mathematics curriculum. New York: A Project of the American Educational Research Association.

Ruseffendi, E. T. (1991). Pengantar kepada membantu guru mengembangkan kompetensinya dalam pengajaran matematika untuk meningkatkan CBSA. Bandung: FPMIPA IKIP Bandung.

Sumarmo, U. et al. (2002). Alternatif pembelajaran matematika dalam menerapkan kurikulum berbasis kompetensi (Unpublished Conference Article). Bandung, Seminar Tingkat Nasional FP-MIPA UPI Bandung).

William, P. (2000). Understanding students' difficulties in reasoning: Part one, perspectives from several fields. Retrieved from http://academic.pg.cc.md.us/ wpeirce/MCCCTR/underst06.html

\section{Copyright Disclaimer}

Copyright for this article is retained by the author(s), with first publication rights granted to the journal.

This is an open-access article distributed under the terms and conditions of the Creative Commons Attribution license (http://creativecommons.org/licenses/by/3.0/). 